\title{
Economic Analysis of Apricot (Prunus armeniaca L.) Based Production System in Trans-Himalayas Region of Ladakh
}

\author{
Stanzin Lakdan ${ }^{1}$, Lobzang Stanzen ${ }^{2}$, Padma Lay $^{3 *}$ and Stanzin Dorjey ${ }^{4}$ \\ ${ }^{1}$ Tata Trusts, Leh-Ladakh, India \\ ${ }^{2}$ SRF, FASAL, Division of Meteorology, SKUAST -Jammu, India \\ ${ }^{3} \mathrm{JRF}$, School of Biotechnology, SKUAST-Jammu, India \\ ${ }^{4}$ Division of Pathology, SKUAST-Kashmir, Wadura, Kashmir, India \\ *Corresponding author
}

A B S T R A C T

\begin{tabular}{|l|}
\hline Ke y w o r d s \\
$\begin{array}{l}\text { Apricot, Harvesting } \\
\text { net, Apricot dryer, } \\
\text { Quality, Quantity }\end{array}$ \\
\hline Article Info \\
\hline $\begin{array}{l}\text { Accepted: } \\
\text { 10 February } 2018 \\
\text { Available Online: } \\
10 \text { March } 2018\end{array}$ \\
\hline
\end{tabular}

Keywords

\section{Introduction}

Apricot (Prunus armeniaca L.) was introduced in India by the European settlers and missionaries during the late $19^{\text {th }}$ century, presently apricot is grown commercially in the hills of Jammu and Kashmir (Ladakh), Himachal Pradesh, Uttaranchal and to a limited extent in the north eastern hills (Tomar and Rehalia, 2004) and the estimated area under fresh Apricot production in Jammu and Kashmir is (6123) hectares (Dar, 2017). Apricot (Prunus armeniaca L.) is considered as most important fruit crop of Ladakh and its
Apricot (Prunus armeniaca L.) is the most important fruit crop of Ladakh district in the state of Jammu and Kashmir and it is grown in the lower belt areas (Takmachik and Lehdo) of Ladakh. Apricot has some comparative benefits and advantages which is the result of different relief. This study reveals the production level (quantity and quality), costs (investment and production costs- divided into material cost and human costs) profit overall investment. Total cost of cultivation of apricot crop recorded Rs/100 trees is 12000/-, Labour cost recorded Rs 28000/- and shared of 100 percent to the total cost. berm size is analyzed for the total cost of cultivation of Apricot, yield/quintals and benefit received on/rupee is Rs.4.71/-, estimated gross return of Apricot was Rs/100 trees is 160000/- and obtained net return was Rs. 132000/-. The use of two technological invention viz., Harvesting net and apricot dryer were proves to be good technology and boon to farmers for saving the apricot productivity. 
Almost every part of the fruit is used by the local inhabitants; ripe apricot is an excellent dessert fruit and is used for table purposes. To date, apart from livestock, apricot is considered to be the only economically-viable agricultural produce having direct influence on upliftment of farming community of the region. Dried apricot/processed apricots were consumed in different forms. Cultivars such as Halman, Raktse-karpo and Nari (Dar, 2017) are some cultivars which are dried whole.

The world's largest producers of dried apricots are Turkey. Organic fruit is darker in color and has a coarser texture. Apricots are good source of vitamin A, Beta carotenoids, potassium and iron. Dried apricot is an important value added product and annually, about 3,000 MT of fresh apricots are processed by traditional drying methods comprising of harvesting, drying, and grading techniques result in high level of wastages in processing and degrade quality in many forms. Farmers have been producing apricots for generations; however, have never have been able to get the right value and proper market for their product.

\section{Materials and Methods}

\section{Data collection}

Data collection was done using structured questionnaire on farmers output, production input variables (No. of apricot trees, labour used, "A" grade apricots production, Marketing price, harvesting cost). A random survey was done and selected 20 farmers from two major apricot grown areas viz., Takmachik and Lehdo village. Cropping practice and fertilizer input employed by farmers were also recorded. Harvesting Net (provided by NGO viz., LEHO and TATA TRUST)were used by farmers for harvesting apricot fruit from the trees, and it is made up of mesh followed by the processing where drying of apricot is done by using Apricot dryer (NGO viz., LEHO and TATA TRUST) which contains 16 trays and 24 trays.

All data on resource use, production cost and outputs were converted to per kanal equivalent and the data has been analyzed, arranged and interpreted through tabulation and simple percentage method.

\section{Objectives of the study}

To analyze change in price of apricots after project intervention.

To evaluate the cost of production per quintal of Apricot on different size farm groups.

Importance of harvesting net to reduce wastage during harvesting.

Importance of apricot dryer in value addition.

\section{Cropping practices employed by farmers}

Farmers involves in the apricot fruit tree growing according to their availability of the land/area in this villages and they used the borders of the field crops for fruit tree planting however they didn't followed any orchard system because of the lack of dissemination of any knowledge or technology in the fur lung areas but Halman variety were the most grown and consider best varieties of Apricot by the farmers as well as local in this area. This was attributed to the following: marketability, sweetness, shelf life, size and storability. So there were no orchard system or specific orchards in these villages are always problem to analyze apricot tree in terms of area.

\section{Harvesting of apricot fruits}

For fresh market the fruits are plucked when they change the surface colour from green to yellow, fully ripe fruits are used for processing (Audergon et al., 1991). Picking/harvesting is done by collecting apricot from trees manually 
by using harvesting net or collected from the grounds which were dropped after ripening or due to wind, animal hindrance. Due to the introduction of harvesting net picking of fruits made easy but it is laborious.

\section{Results and Discussion}

Above surveyed questionnaire were analyzed and interpreted the cost of cultivation, profitability, use of harvesting net and uses of apricot dryer by farmers in apricot trees grown areas (Takmachik and lehdo).

\section{Cost of cultivation for apricot in sample farms}

The cost of cultivation indicates the investment on the variable inputs used in the cultivation and the services rendered by fixed assets. The cost input used by cultivators in the cultivation of Apricot was calculated for contribution of each input in total costs in all the three different size farm groups. The cost of cultivation of Apricot of sample farms is worked out in Rs/100 trees and presented in Table 3. It reveals that overall cost of cultivation of Apricot crop was Rs/100 trees is 12000 /. . The all contribution have been observed in family labour use with Rs 28000 /- and shared of 100 percent to the total cost. Still these areas is not adopted any plant protection measure by them and applying of manure and fertilizer to apricot trees is nil.
Most of laborious works are done by family members with no any hired labours. Apricot production is less laborious as compared to other field crop in the area most of laborious works are done after harvesting of fruits.

\section{Profitability in cultivation of apricot}

A brief summary of the costs and return calculated by selecting small farm size is represented on gross return received; net returns obtained after subtracting the total cost of cultivation of Apricot, yield per quintals of Apricot production and benefit received on per rupee investment in Apricot cultivation is Rs.4.71/- (Table 4). Overall, estimated gross return of Apricot was Rs/100 trees is 160000/and obtained net return was Rs. 132000 /.

\section{Use of harvesting net}

Harvesting Net made picking easy for the farmers of villages which shown increment in the production of apricots (Takmachik 4 tonnes and Lehdo 2 tonnes) Table 5. Earlier when harvesting net was not introduced about half of the production was waste during the season because of spoilage in ground or breakage of apricot tree branches after dropping. Harvesting net proves to be great boon to farmers in saving their all apricot productivity. And surveyed to villages found the data on harvesting net as below:-

Table.1 Cropping practices adopted by farmers

\begin{tabular}{|l|l|l|l|}
\hline \multicolumn{1}{|c|}{ Characteristics } & \multicolumn{2}{|c|}{ Categories } & \multicolumn{1}{c|}{ Percentage } \\
\hline Cropping system & Apricot & Local technology & $\mathbf{1 0 0 \%}$ \\
\hline Apricot & Variety & Halman & $\mathbf{6 2 \%}$ \\
\cline { 2 - 4 } & Wild type & Wild & $\mathbf{3 8 \%}$ \\
\hline Method of seed & Seeds & Direct seeding & $\mathbf{4 0 \%}$ \\
\hline planting & nursery & Transplanting & $\mathbf{6 0 \%}$ \\
\hline Farm size & $>100$ trees & Small & $\mathbf{6 0 \%}$ \\
\hline & 150 trees & Medium & $\mathbf{3 0 \%}$ \\
\hline & $<200$ trees & Large & $\mathbf{1 0 \%}$ \\
\hline
\end{tabular}


Table.2 Input use for cultivation of apricot in sample farms (in Kanal)

\begin{tabular}{|c|c|c|c|c|c|}
\hline S.No & Particular & \multicolumn{3}{|c|}{ Farm Size } & Average \\
\hline & & $\begin{array}{l}>100 \text { trees } \\
\text { Small }\end{array}$ & $\begin{array}{l}150 \text { trees } \\
\text { Medium }\end{array}$ & $\begin{array}{l}<200 \text { trees } \\
\text { Large }\end{array}$ & \\
\hline 1. & Seeds & 0 & 0 & 0 & 0 \\
\hline \multirow[t]{2}{*}{2.} & Manure in $\mathrm{Kg}$ & 0 & 0 & 0 & 0 \\
\hline & & \multicolumn{4}{|c|}{ Fertilizer in $\mathrm{Kg}$} \\
\hline 3. & Urea & 0 & 0 & 0 & 0 \\
\hline \multirow[t]{2}{*}{4.} & DAP & 0 & 0 & 0 & $\mathbf{0}$ \\
\hline & & \multicolumn{4}{|c|}{ Labour in Mandays } \\
\hline 5. & Family Human Labour & 30 & 60 & 120 & 70 Days \\
\hline 6. & Hired Human Labour & 0 & 0 & 0 & $\mathbf{0}$ \\
\hline
\end{tabular}

Table.3 Cost of cultivation of apricot on different sample farms (Rs/Kanal)

\begin{tabular}{|c|c|c|c|c|}
\hline Particular & $\begin{array}{l}>100 \\
\text { Trees } \\
\text { Small }\end{array}$ & $\begin{array}{l}150 \\
\text { Trees } \\
\text { Medium }\end{array}$ & $\begin{array}{l}<200 \text { Trees } \\
\text { Large }\end{array}$ & Average \\
\hline & \multicolumn{4}{|c|}{ Inputs } \\
\hline a)Hired Human Labour & 0 & 0 & 0 & 0 \\
\hline b) Family Labour & 12000 & 24000 & 48000 & $28000(100 \%)$ \\
\hline c) Cost of seed & 0 & 0 & 0 & 0 \\
\hline d) Manure and fertilizer & 0 & 0 & 0 & 0 \\
\hline e) Irrigation & 0 & 0 & 0 & $\mathbf{0}$ \\
\hline f) Plant protection & 0 & 0 & 0 & $\mathbf{0}$ \\
\hline g) Rental value of owned land & 0 & 0 & 0 & 0 \\
\hline Total Input Cost & 12000 & 24000 & 48000 & $28000(100 \%)$ \\
\hline
\end{tabular}

Table.4 Gross return from "A" graded apricot

\begin{tabular}{|l|l|c|}
\hline S.No & Particular & Farm Size (100 Trees) \\
\hline 1. & Production of Apricot (Quintal /100 trees) & 4 quintals \\
\hline 2. & Gross return $(\mathrm{Rs} / 100$ trees) & Rs $160000 / 100$ trees \\
\hline 3. & Total Cost(Rs/100 trees) & Rs. $28000 /-$ \\
\hline 4. & Net return(Rs/100 trees) & Rs. $132000 /-$ \\
\hline 5 & B:C Ratio & 4.71 \\
\hline
\end{tabular}


Table.5 Harvesting net data before and after project intervention

\begin{tabular}{|l|l|l|}
\hline Village & Before & After \\
\hline Takmachik & 2.2 tonnes & 4 tonnes \\
\hline Lehdo & 1 tonnes & 2 tonnes \\
\hline
\end{tabular}

Note: Sample size of hundred trees

Table.6 Apricot dryer data before \& after project intervention

\begin{tabular}{|l|l|l|}
\hline Village & Before & After \\
\hline Takmachik & Rs.150/kg & Rs.450/kg \\
\hline Lehdo & Rs.120/kg & Rs.350/kg \\
\hline
\end{tabular}

\section{Use of Apricot Dryer}

This technique improves the quality of dried apricot and by improved practices of harvesting and drying. And after introduction of apricot dryer the price of Harman variety of apricot went to triple times than what they sold during by traditional drying methods. Such techniques deliver the apricot of best quality. The below mentioned data is prove of successful intervention and technology adopted by villager lead to more value addition of their fruit. The data is based on apricot sold during this year. And more innovation is needed in solar dryer to reduce drying period, protection from rain because apricots were drying mainly in short rainy season of Ladakh. When apricot was dried by conventional method the farming community got only Rs.120-150/kg (Table 6) and after introduction of apricot dryer there is increased in sales as well as the hike in prices of Rs.350-450/kg for " $A$ " graded apricots.

\section{Acknowledgements}

The authors are thankful to the Tata trusts Leh Ladakh for providing sufficient help in conducting survey and dissemination of new technology to the far flung villages.

\section{References}

Audergon, J.M. Dulffillo, J.M. Souty, M. Breuils, L. and Reich, M. 1991. Biochemical and physiochemical characterisation of 400 apricot varieties. Consequences in the apricot selection and improvement process. Acta hortic. 293: 111-119.

Dar, F.A. 2017. Production of fresh and dry fruits, a district wise analysis in Jammu and Kashmir International Journal of Applied Research. 3(7): 336-340.

Tomar, C.S., and Rehalia. 2004. Recent trends in Horticulture in the Himalayas, book chapter pp 117-123.

\section{How to cite this article:}

Stanzin Lakdan, Lobzang Stanzen, Padma Lay and Stanzin Dorjey. 2018. Economic Analysis of Apricot (Prunus armeniaca L.) Based Production System in Trans-Himalayas Region of Ladakh. Int.J.Curr.Microbiol.App.Sci. 7(03): 1001-1005.

doi: https://doi.org/10.20546/ijcmas.2018.703.119 